\title{
KULTURA UKRAIŃSKA, WIDZIANA PRZEZ GRANICE CZYLI ODKRYWANIE OBSZARÓW NIEWIEDZY
}

(recenzja na książke: Ковальчук Н. Д. Символічні структури етнокультурного процесу в Україні / Ковальчук Н. Д. - К.: НАКККіМ, 2012. 262 c.)

$\mathrm{Na}$ początek winna jestem wyjaśnienie motywów, skłaniających do lektury książki Natalii Kowalczuk (Struktury symboliczne procesu etnokulturowego na Ukrainie [tłum. RK]). Motywy te są bowiem istotne dla zrozumienia sposobu percepcji tej rozprawy. Strategia taka, zalecana przez wielu badaczy z różnych dyscyplin humanistycznych ${ }^{1}$, a polegająca na określeniu pozycji podmiotowej czytelnika/autora wobec analizowanego tekstu, pozwala na zmniejszenie ryzyka stworzenia pozoru obiektywizmu, który będzie skrywał zarówno uwikłanie kulturowe, jak i możliwe uprzedzenia. Wskazanie wprost, że ryzyko takie jest możliwe po stronie czytelnika, należącego do innego kręgu kulturowego, nawet gdy nie ma bezpośredniego związku pomiędzy tym kręgiem, a tym drugim - do którego należy dzieło - jest krokiem uzasadnionym. W przypadku, gdy kręgi te nie tylko się stykają, ale gdy styczność ta ma charakter wysoce konfliktogennego, sięgającego głęboko w historię, uwikłania, zaznaczenie tej okoliczności jest niezbędne.

Dlaczego w Polsce należałoby czytać prace uczonych ukraińskich, zwłaszcza gdy podejmują oni badania antropologiczne, dotyczące własnej kultury? Pytanie to jest bardzo niewygodne; a jak bardzo, to już wiadomo $\mathrm{z}$ recepcji znakomitej pracy Daniela Beauvois ${ }^{2}$. Jego książka, choć oparta na niewykorzystywanych przez polskich badaczy źródłach, wzbudziła konsternację i opór: autor przedstawił bowiem obraz relacji polsko - ukraińskich niepokrywający się ze schematem, jaki w piśmiennictwie polskim został uznany za wzorzec. Temu wzorcowi też należy się krótka charakterystyka: jego właściwością fundamentalną jest swoiste wyjęcie spod krytyki, a nawet uchylenie wobec niego powinności refleksji. ${ }^{3}$ Nieodzownej, gdy zważyć, że refleksja humanistyczna od blisko półwiecza skupia się także na własnych naiwnościach i kwestionuje prawomocność utożsamiania naiwności z oczywistością. $\mathrm{Na}$ czym ta krytyczna autorefleksja humanistyki polega, widać w jednej $\mathrm{z}$ pionierskich prac Edwarda W. Saida z tego zakresu, w Kulturze i imprerializmie ${ }^{4}$. Tymczasem jest tak, jakby ten nurt myślenia nie istniał; i polski czytelnik, zainteresowany problematyką ukraińską (ale też białoruską czy litewską) nadal pozostaje na tym etapie, który w (post)kolonialnej tradycji brytyjskiej wyznacza $R a j$

\footnotetext{
${ }^{1}$ Zalecenia np. G.Chakravorty Spivak (Can the Subaltern Speak? (w:) C. Nelson, L. Grossberg, Marxism and the Interpretation of Culture, Univ. of Illinois Pr., 1988) czy D. LaCapry (np. Historia w okresie przejściowym. Doświadczenie, tożsamość, teoria krytyczna, tł. K. Bojarska, Kraków 2009 s. 26 - 78;) są uznawane za kanoniczne wskazówki z zakresu metodologii badań humanistycznych. Por. także: Deltecheva R., The difficult topos in-between: The East Central European cultural context as a post-coloniality, „Sarmatian Review” 18 (2)/1998, s. 557 - 562.

${ }^{2}$ D. Beauvois, Trójkąt ukraiński. Szlachta, carat i lud na Wotyniu, Podolu i Kijowszczyźnie, tł. K. Rutkowski, Lublin 1005.

${ }^{3}$ Wprowadzenie krytycznego dyskursu w tym zakresie jest stosunkowo świeże. Zob. J. Niedźwiedź, Sarmatyzm czyli tradycja wynaleziona, „Teksty Drugie”, t. „Zwrot sarmacki” 1/2015, s. 46 - 53; A. Kubiak, peryferyjn samosterowność i ambiwalencja, tamże, s. 96 - 106. Ważną książką, której istotnym watkiem jest konfrontacja dyskursu kresoznawczego z historią jest Fantomowe ciało króla. Peryferyjne zmagania z nowoczesna forma, Kraków 2011.

${ }^{4}$ E.W. Said, Kultura i imperializm, tł. M. Wyrwas - Wiśniewska, Kraków 2009. .
} 
Nostalgia; czyli na etapie „dyskursu kresoznawczego”. To jednak, co istotnie różni ów dyskurs kresoznawczy od dyskursu raj nostalgii, to brak świadomości, że ów dyskurs jest ograniczony do jednej pozycji - do pozycji strony, w pewnym okresie historycznym dominującej politycznie i starającej zapewnić sobie dominację $\mathrm{w}$ sferze symbolicznej.

Niedostateczność takiego dyskursu, gdy zostaje zauważona, skłania przynajmniej do zastanowienia się nad tym, jak ta relacja była i jest postrzegana $z$ drugiej strony. Jeśli zaczyna się dostrzegać ideologiczny charakter dyskursu kresoznawczego (podobnie, jak każdego dyskursu, wytworzonego $\mathrm{w}$ realiach kolonialnych i postkolonialnych ), rodzi się problem następujący: już wiadomo, jak terytoria ongiś podporządkowane widzą dawni hegemonowie - ale czym one są w świadomości swoich rdzennych mieszkańców? Już wiadomo, jak kultura takich terytoriów została „zorientalizowana": sprowadzona do wygodnej i legitymizującej roszczenia do dominacji symbolicznej formuły „niższości cywilizacyjnej”, „kultury przedpiśmiennej” czy „kultury ludowej”. Czym jednak ta kultura jest dla ludzi, którzy ją tworzyli i którzy byli przez nią kształtowani? Poznawczo bardziej znaczące jest dotarcie do tego, czym jest kultura ukraińska dla Ukraińców (podobnie, jak indyjska dla Hindusów), niż poprzestawanie na przyjęciu, że obraz tej kultury, widziany z zewnątrz, jest nie tylko w pełni wiarygodny, ale też jedyny możliwy.

Natalia Kowalczuk podjęła się zadania imponującego: przedstawienia zasobów symbolicznych, stanowiących postawę odrębności kultury ukraińskiej i pozwalających na określenie tożsamości etnokulturowej. Czytelnik „zewnętrzny”, obciążony dodatkową niedoskonałością, jaką jest skromna znajomość języka, otrzymuje bardzo mu potrzebną lekcję rozczarowania zakresem swojej niewiedzy. I więcej jeszcze: konfrontując przedstawiony przez Kowalczuk fundamentalny dorobek kulturowy Ukrainy $\mathrm{z}$ obrazami, funkcjonującymi $\mathrm{w}$ obszarze kultury własnej, czytelnik może sobie - z pożytkiem - uprzytomnić stopień „zorientalizowania” tego obrazu.

$\mathrm{Na}$ dwa zjawiska, przedstawione w książce, a mające tę trzeźwiącą właściwość in concreto dla czytelnika polskiego, chciałabym zwrócić szczególną uwagę. Pierwsze to obszerna analiza myśli G. Skoworody, wraz z charakterystyką kulturowego kontekstu jego twórczości (r. 3.) ; druga - to analiza genezy i swoistości ukraińskiej nieufności wobec prawa stanowionego.

Zetknięcie się tylko ze streszczeniem oraz - z konieczności - próbkami twórczości całego ukraińskiego baroku wywołuje głęboką konsternację. Z przyczyn już wspomnianych: bo oto okazuje się, że ukraińskie życie intelektualne było nie tylko bogatsze, niż to, które czytelnik znał ze ,zorientalizowanego" obrazu - ono w wielu punktach było bogatsze, niż życie intelektualne ówczesnego hegemona. Poezja ukraińskiego baroku ukazuje $\mathrm{z}$ jednej strony zakorzenienie $\mathrm{w}$ duchowości chrześcijańskiej, sięgające o wiele głębiej, niż konwencjonalna pobożność; z drugiej zaś - naturalną absorpcję wątków antycznych. I wreszcie, ze względu na stopień poetyckiej zażyłości z toposami, później nazwanymi ludowymi, twórczość ta sprawia

\footnotetext{
${ }^{5}$ To poręczna kategoria Saida, który bardzo umiejętnie wykazał polityczno-ideologiczną zawartość dyscypliny naukowej, znanej jako orientalistyka. Zob. E.W. Said. Orientalizm, tł. M. Wyrwas - Wiśniewska, Poznań 2005 (2), s. $49-53$.
} 
wrażenie biegnącej równolegle z nowymi kulturowymi prądami w Europie. Nie jest ona „odbiciem” ani „naśladownictwem” - nawet niekoniecznie podzielając heglowską koncepcję Ducha Czasu, można odnieść wrażenie, że w tym czasie Ukraina, niebędąca odrębnym bytem geopolitycznym, była miejscem kulturowo autonomicznym. Takim przy tym, którego związków z kulturą europejską, płodnych, bo wnoszących duchowość chrześcijaństwa prawosławnego, zanegować nie można.

Tu rodzi się pytanie: na ile formowanie się kultury ukraińskiej oraz jej toposy są bliskie np. kulturze serbskiej? Na ile obecne są w niej problemy, wskazane przez M. Bobrownicką jako charakterystyczne dla krajów słowiańskich? ${ }^{6}$

Drugie z tych zjawisk, stosunek do prawa stanowionego, wymaga - jak się zdaje - dalszych badań, prowadzonych już wprost $\mathrm{z}$ uwzględnieniem narzędzi, wypracowanych przez teorie postkolonialne. ${ }^{7}$ Polski czytelnik ma tu do przepracowania jeszcze więcej, niż w przypadku rozległej niewiedzy o ukraińskim życiu intelektualnym i o kulturze literackiej. Jest bowiem przyzwyczajony do szczególnie szkodliwego stereotypu „cywilizacji turańskiej” - konceptu Feliksa Konecznego, który twierdził, że ta „cywilizacja” oparta miałaby być na braku prawa. Szczególna szkodliwość tego konceptu polega na tym, że nadal jest on podtrzymywany bezkrytycznie $;^{8}$ nie jest on konfrontowany choćby z pytaniem o to, jakie mianowicie należałoby wskazać źródła prawa w nowożytnej historii Ukrainy. Jakkolwiek wskazywać, nie sposób uciec przed koniecznością uznania, że prawo stanowione było prawem, obliczonym na ustanowienie i utrzymanie Ukrainy $\mathrm{w}$ pozycji podporządkowanej. Toteż poszukiwanie symbolicznej ochrony w prawach serca, a nie $\mathrm{w}$ prawie stanowionym jest nie tylko uprawnioną reakcją, ale też świadectwem logicznego wnioskowania, że obce prawo nie jest nadawane po to, aby chronić tych, którzy mają je przyjąć. Skądinąd, rzecz to zadziwiająca, że tak właśnie - oporem przed obcym prawem - tłumaczy się w Polsce własny osobliwy stosunek do prawa stanowionego... To jest z kolei zadaniem dla badań polskich: zmierzyć się ze źródłami tej dwoistości, która nakazuje innym odmawiać prawa do oporu, które jako oczywiste - przyznaje się własnej wspólnocie.

Głębsza ocena książki Natalii Kowalczuk wymagałaby znacznie lepszej znajomości języka ukraińskiego i większej wiedzy o kulturze Ukrainy. Mnie zabrakło w rozważaniach Autorki wyraźniejszego zaznaczenia specyficznych i wysoce niekorzystnych warunków, w jakich ta kultura się formowała. Czytając kluczowy rozdz. 2 i wgłębiając się $\mathrm{w}$ analizy, zawarte $\mathrm{w}$ rozdziale następnym, można nieraz odnieść wrażenie, że było intencją Autorki pokazać, że ta kultura rozwijała się ,jak w każdym innym kraju" (zostawiając w domyśle mimo wszystko). A jednak, z punktu widzenia czytelnika - amatora, ta wysoka kultura rozwijała się inaczej: pomimo warunków zewnętrznych, które tej kulturze nie sprzyjały i były pomyślane na to, aby ją marginalizować. Ta tendencja prezentacji kultur krajów kiedyś kolonizowanych jako wtórnych i marginalnych jest nadal obecna. Dlatego mam wrażenie, że

\footnotetext{
${ }^{6}$ M. Bobrownicka, Pogranicza w centrum Europy, Kraków 2003.

${ }^{7}$ J. Le Rider, Mitteleuropa, Centraleuropa, Mittelosteuropa: A Mental Map of Central Europe, „European Journal of Social Theory” - „Mitteleuropa: Symbolic Geographies and Political Vision”, 1101 (maj 2008), s.155 - 169.

${ }^{8}$ Siły tego oporu można domniemywać choćby z tej okoliczności, że pomimo wielości dyskusji o problematyce Europy Centralnej czy też Wschodniej pewne publikacje (v. L. Wolff, Inventing Eastern Europe: The Map of Civilisation on the Mind of Elightenment, Stanford 1994, a także wspomniana uprzednio R. Deltecheva) nie znajdują żadnej recepcji.
} 
dostępność książki Natalii Kowalczuk dla polskich czytelników, zwłaszcza dla badaczy, zajmujących się zagadnieniami antropologii społecznej, mogłaby być impulsem do podjęcia badań i nad granicami własnych uprzedzeń, i nad urealnieniem obrazu kultury sąsiedniej.

\author{
Romana Kolarzowa \\ Prof., dr. hab. \\ Instytut Filozofii \\ Uniwersytetu Rzeszowskiego \\ (Rzeszów, Polska)
}

